\title{
Exploration on the School-enterprise Collaboration Model in Design Specialty from the Perspective of Employment
}

\author{
Taking the Exhibition Design Specialty as an Example
}

\author{
Yifeng Du \\ Zhuhai College of Jilin University \\ Zhuhai, China 519041
}

\begin{abstract}
Starting from the perspective of employment, this paper takes the exhibition design specialty as an example to explore school-enterprise collaboration ways, and improves the effectiveness and intensity of practical teaching. Starting with adjusting semester teaching plan, this paper explores the cooperative mode that the schools are in active position, the cooperation mode in which the enterprises are in an active position, and win-win school-enterprise cooperation model. Finally, this paper develops an effective assessment mechanism. Also, it has put forward future development prospects.
\end{abstract}

Keywords - employment; exhibition design; school-enterprise collaboration model

\section{INTRODUCTION}

The exhibition design was born in the context of the rapid development of the exhibition industry. As an emerging sunrise industry, China's exhibition industry requires a large number of talents. The exhibition design specialty in Zhuhai College of Jilin University was established earlier. It has been developed for more than 10 years. It has become a key discipline with strong discipline foundation, reasonable teacher structure and clear training objectives. In order to adapt to the development and needs of the times, the future talent training goal is to be able to adapt to the needs of China's exhibition industry and economic and social development, and cultivate high-quality applied, complex, innovative talents with a sense of social responsibility, strong practical and innovative capabilities, international vision and competitiveness.

In order to achieve this goal, it requires improving students' practical ability. School-enterprise cooperation is an effective way. School-enterprise cooperation means cooperation between schools and enterprises. They would foster and cultivate comprehensive practical talents with practical ability and real skills, make full use of the school's professional teaching resources to enrich the theoretical foundation, and utilize the production advantages and practical experience of enterprises to enhance students' practical ability. In order to achieve cooperation with the company, we must first adjust the teaching plan and join the practice link.

\section{AdJUSTMENT OF TEACHING PLAN}

In order to achieve school-enterprise cooperation, we must first develop practical and feasible personnel training programs, and develop sound and complete teaching programs to better integrate with enterprises. It can be done from the following aspects.

First, we should increase the proportion of practical teaching when formulating training programs, increase the content of practical training, and focus on the combination of innovation and practice: such as the comprehensive training courses added in this major. At present, the comprehensive training course currently added at the end of each semester is comprehensive training and evaluation for students in one semester. Students are required to be integrated with the actual project. The teacher introduces the enterprise project into the classroom, and the students are trained and promoted in the actual project.

Second, we should increase the intensity of practical teaching, and adjust the theory and practice time in each professional course of the major. The practice in Zhuhai College of Jilin University is to add practical teaching links in the professional courses of the exhibition design in college junior. It should achieve an organic combination of theory and practice in each course.

Third, we should encourage teachers to bring practical projects into the classroom. Teaching emphasizes the combination of "work" and "study". In the process of training, the students can experience the real working state. The school can also establish a practical teaching platform to build classroom "simulation construction" teaching mode, expand the training base, add construction materials and construction tools, and establish an incentive mechanism from professional characteristics and analysis on social needs. Taking the study group as a unit, the school could encourage students with sufficient resources to guide other students, compare the learning situation of each group, and reward the progressive group to mobilize students' learning initiative and enthusiasm. 
Fourth, jointly with enterprises, we regularly invite industry professionals to give lectures in campus. On the other hand, teachers are assigned to work in the enterprise to exercise their professional skills and enhance their professional skills. In the future, an effective combination of production, education and research will be formed. It provides an excellent space for the graduation creation and graduation internship of the students of the exhibition. The strict management philosophy of the company, the enterprise and the factory, the requirements of the position and the professionalization of the knowledge, etc. for the students will enable the students to quickly overcome the shortcomings of "high-handedness", correctly examine themselves and establish a good employment concept. When formulating the goal of talent training, the school will push forward in reverse according to the job requirements of the enterprise, analyze the employment standards of the industry, scientifically construct the curriculum system, and adjust the teaching content in a timely manner. At the same time, through the understanding of corporate culture, students can be encouraged to establish confidence in self-employment.

\section{SCHOOL-ENTERPRISE COOPERATION MODEL}

The needs of society and the rapid development of the industry have made exhibition design professionals have a comprehensive ability. Through cooperation between the schools and companies, practical teaching has become necessary and distinctive model for exhibition design education. The development of the exhibition design specialty has experienced three stages in the process of cooperation between the school and the enterprise from the initial exploration to the right track.

\section{A. Cooperation Mode in Which School Is in an Active Position}

In China, the exhibition design specialty started late, and there is no unified and mature teaching and practice model that can be used for reference. Therefore, it is at the stage of exploration in practice. At present, most colleges take the form of actively connecting with enterprises and establishing contacts. In the curriculum, teaching, teachers and other aspects, the schools will ask the company for assistance, and invite business experts to the school to serve and guide, or send teachers to the enterprise for short-term training and improvement. This kind of cooperation can improve the professionalism of teachers by means of the strength of enterprises. And it can cultivate professional teachers by means of enterprises to improve the professional skills of teachers. For enterprises, the experts of enterprises can play very good publicity role. Enterprise experts have their own advantages. They often have years of rich work experience in the enterprise, are familiar with the industry and the field, and regard the lecture as a training course similar to training employees. This characteristic determines the difference between enterprise experts and full-time teachers. These enterprise experts often have rich experience and good practice in certain course or field. However, for professional knowledge, there is a lack of cooperation, which requires the cooperation of university teachers and enterprise experts. On the one hand, teachers constantly draw professional knowledge from industry experts, and schools can also send teachers to work. On the other hand, professional programs can also offer specialized courses or lectures in schools. It can improve the practicality of college courses. It's complementary.

\section{B. The Cooperative Mode in Which Enterprises Are in an Active Position}

With the continuous development of the exhibition industry, especially the changes in the demand for exhibition design talents, the singular talents from the past design gradually become composite and comprehensive talents. The relationship between enterprises and universities is also constantly changing. Exhibition companies began to recognize the importance of talents. If they want to find qualified talents that meet the needs of enterprises, they should go deep into colleges and universities to help universities actively cultivate high-quality and comprehensive talents, and shape talents in a tailor-made way to adapt to the development needs of company. As a result, many exhibition companies have begun to contact universities. And they are willing to cooperate with universities in various forms. In this process, the practice teaching of colleges and universities has been developed rapidly. The exhibition design specialty also has more opportunities to select suitable enterprises to cooperate. Those enterprises with lower quality or smaller enterprises have been eliminated in the fierce competition. There is no longer a chance to participate in. The more powerful enterprises selected by the company have developed rapidly in this process and formed double-direction compensation. In particular, the participation of some well-known foreignfunded enterprises has made the personnel training in the exhibition industry with nationalized vision.

\section{School-enterprise Double-direction Collaboration, Co- cultivation and Win-win Model}

The development of the exhibition industry has been in existence for decades. After the Shanghai World Expo, exhibition companies and universities are facing changes and transformations. The relationship between universities and enterprises is also changing. The universities and enterprises hope to achieve win-win situation in the context of mutual benefit, and also hope to build a platform for long-term cooperation in the future. On the one hand, colleges and universities need to find more suitable enterprises to cooperate with, and enterprises also pay more attention to long-term effects. During this period, the cooperation between universities and enterprises has entered a period of linkage development, realizing a new mode of mutual cooperation between schools and enterprises.

The first is the introduction of project-based cooperation. Colleges and universities connect with enterprises in the form of project-based cooperation, and project-based teaching is substituted into them when formulating the training plan. For example, when we develop the professional design plan for exhibition design, we will start from the sophomore year. At the end of each semester, we 
will join the two-week comprehensive training, which is to introduce the practical teaching. Here, teachers can introduce corporate projects into the classroom, and companies can send instructors to guide the students and make the cooperation. In the cooperation, it has cultivated the students' practical ability, work ability and comprehensive ability. In addition, in the formulation of the training program for the senior year, the cooperation of the project system was also introduced. In the teaching practice of graduation design, students are allowed to use enterprise projects as graduation design works. The students' work in the course of graduation design is the classroom work and the actual project work. It can not only exercises the initiative and creativity of the students, but also exercise the students' practical ability. By doing half the work, it will get double the result.

Second is to establish the class in which the students are signed by the company. Universities and enterprises jointly set up the class in which the students are signed by the company in college courses. This class is for the enterprise to train appropriate exhibition professionals, and the selection of teachers is done by the school and the enterprise. It adopts separate management and individual training, targeted training mode and targeted teaching methods. This form not only realizes the special cultivation of specialized talents, but also tends to be more flexible in the form of teaching. For example, the classroom is divided into two parts of teaching. One department is carried out in the school, and the teaching of another department begins in the enterprise content. This form adapts to the development of the times and the needs of enterprises. Students are exposed to industry trends as early as possible during their school days. And they are more in line with actual needs in the training of professional skills. It is new mode of effective training for school-enterprise cooperation.

Finally, the working system is implemented. It should set up a studio in the teaching and research office of the exhibition, such as the skill master studio or the teaching master studio. This kind of studio is a form of studio that accepts corporate funding. Students can take the initiative to join the studio in the sophomore year. The selection of the members of the studio is carried out according to the principle of merit-based admission. The members are also assessed regularly to select the superior and eliminate the inferior. The studio adopts the method of cooperating with the enterprise and accepts the enterprise order. The students can directly contact the actual items at the school. The combination of "work" and "study" enables the students to continuously improve their professional quality and professional skills in the project. Then, the students are fully prepared for the formal jobs in the future.

\section{To DEVELOP AN EFFECTIVE ASSESSMENT MECHANISM}

First, under the school-enterprise cooperation model, the improvement of students' practical ability is mainly in the aspects of internship and professional practice. This requires the teaching department to formulate corresponding evaluation system. Then, it could evaluate the practical results. Professional practice should be carried out in stages.
Each stage should develop appropriate assessment criteria. And the corresponding credits would be reckoned in the semester. When the students enter the enterprise, the relevant person shall be the external tutor and supervise the assessment. The students shall complete a certain amount of class hours and have certain practical results. Then, they can count the corresponding credits. The tutors outside the school should have a certain amount of class hours, and the school will give a certain amount of tuition fees. If the students have design results during the internship of the enterprise and the result shall be adopted by the enterprise, the students would have corresponding marks. The schools should encourage them. The schools should regularly invite the enterprise experts to introduce the work experience, introduce the knowledge and skills that the students should master, and summarize the effect of the students during the internship.

Second, in order to improve the quality of teaching, teachers first enter the enterprise to have the internship. And the school should formulate corresponding management methods to supervise and evaluate the teaching activities of teachers. Due to the strong timeliness and flexibility of the exhibition design, students or teachers should participate in the company's projects in a timely manner. And it is necessary to consider the fixed and flexible measures in the development of the teaching plan. In order to better achieve the school-enterprise cooperation model, the schools should apply this model in the teaching, organize a fixed teaching team, and assign a team to each course. In the professional courses, each teacher undertakes different teaching tasks. The current number of students in each class is about 20 people. It brings certain difficulties to the management of teachers when they go to the enterprise. The students can be led by the teachers to conduct inspections or visits. The number of students in each group is about 7 people, which is convenient for management and guidance. Teachers should enter the enterprise for more than three months a year. During the internship period, the school or department should give a certain amount of allowance, which is included in the annual workload. If design result is adopted during the internship, the enterprise shall pay a certain amount of remuneration, and a certain score shall be included in the calculation of the workload of the school. The teacher is supervised by the enterprise during the internship period. After the internship period, the enterprise gives the corresponding assessment results as a reference for the teacher's job evaluation.

\section{CONCLUSION}

School-enterprise cooperation is proved to be a viable and beneficial model in many universities and professional teaching. Especially for the more practical professions, the status quo of the industry cannot be separated from the teaching. Before starting cooperation, colleges and universities must define professional positioning and cooperation goals. And the schools should cooperate with enterprises that have the same concept to achieve equal status and win-win goals according to their own characteristics. The schools could use cooperation with 
companies as a useful supplement to education. Conditional cooperation enables the two parties to jointly build a platform. Taking project-based teaching as an opportunity, academic and practical values could be reflected in the respective fields in both schools and enterprises. In the end, the teaching model of higher education is more abundant and adaptable. The students who are co-cultivated can have strong comprehensive ability.

\section{REFERENCES}

[1] Guo Xinbao. Promoting School-enterprise Cooperation to Improve China's Scientific and Technological Competitiveness [M]. Beijing: Metallurgical Industry Press. 2009. 郭新宝. 促进校企合作提高我国 科技竞争力【M】.北京: 冶金工业出版社. 2009.

[2] Zhong Heping. Research on the Relationship Between Redundant Resources of Enterprises and Cooperation Between Schools and Enterprises [M]. Beijing: Economic Science Press. 2018. 钟和平. 企 业尣余资源与校企合作创新的关系研究【M】. 北京: 经济科学 出版社. 2018.

[3] Ren Junqing. Research on School-enterprise Cooperation on Serviceoriented Regional Education System [M]. Higher Education Press, 2016. 任君庆.服务型区域教育体系的校企合作研究【M】.高等教 育出版社. 2016.

[4] Luo Yan, Gao Jiayang. Research on the Human resources Schoolenterprise Cooperation: Taking the Human Power Practice Cooperation Between South China Normal University and Shenzhen Sanhe as an Example [M]. Beijing: People's Daily Press, 2016. 罗 燕、高嘉阳. 人力资源校企合作研究: 以华南师大与深圳三和的 人力实践合作为例【M】.北京：人民日报出版社出版社. 2016 . 